\title{
THE BUILDING OF A DEMOCRATIC SOCIETY AND REFLECTION OF PEOPLE'S FACTOR IN THE NARRATIVE «THE DECEIVED STARS» BY M.F.AKHUNDZADEH
}

Abstract: The article analyzes the problems of a democratic society building and the development of people's factor in the narrative "The Deceived Stars by M. F. Akhundzadeh. In the article it is noted that most of literary scholars dealing with $\mathrm{M}$. F.Akhunzadeh's narrative "The Deceived Stars" wrote that the author exposed the Eastern despotism in the example of Shah Abbas character, and created the character of a just ruler by the image of Yusif Sarraj. The work has been analyzed as the confrontation of despotism and justice in the example of these two persons so far. In the article one of the thoughts is that the analysis of the work in this context does not enable us to accurately define the author's main idea and clear up the causes that led Yusif Sarraj to defeat. The author wanted to point out from the standpoint of enlightenment that as long as people are politically passive or indifferent to their destiny, they will never be free. Yusif Sarraj who came to power without people's will suffers a defeat due to their indifference. M.F. Akhundzadeh's thoughts on people's government, active and educated people have been summarized in the article. It is noted that M. F. Akhundzadeh benefited from the doctrines of European philosophers, including J. Milton and J. S. Millin in the issues of building a democratic society.

Keywords: M. F. Akhundzadeh, despot, just ruler, democratic society, the factor of people, people's government

\section{Introduction}

The process of building a democratic and civic society is one of the

\footnotetext{
${ }^{1}$ Leading researcher at the Institute of Literature after named Nizami Ganjavi National Academy of Sciences of Azerbaijan, doctor of philosophy in Philology, associate Professor. E-mail: shindi61@ mail.ru.ORCID: https://orcid.org/0000-0002-7238-5216
} 
leading tendencies in modern times. Although these tendencies started in the XX century, the roots of these ideas go back to far old times in the works of Azerbaijani thinkers and philosophers. The works of one of the prominent representatives of Azerbaijani literature Mirza Fatali Akhundovone are no exception from this standpoint.

The most important problems that made Mirza Fatali Akhundzadeh (1812-1878) who was the founder of Azerbaijani dramaturgy and realistic artistic prose and the first alphabet reformer in the East think for all his life, were problems of building a democratic society, prosperity of the nation he belonged to and its development to the level of civilized nations of the world. Analyses show that in his rich literary, scientific-philosophical and epistolary heritage he consistently kept these issues in the center of attention while corresponding with his contemporaries, and developed his thoughts and ideas into a whole conception. In a democratic society building process he directly based on European experience and European philosophical thoughts that he was well aware of. The protection of human rights, provision of freedom of speech and pluralism of ideas, formation of parliament and government ruled by laws constituted the base for the writer's conception.Yet, Mirza Fatali Akhundzade understood well that in societies dominated by mass illiteracy and religious fanaticism, and where the concervative forces exercise their hegemony it was difficult to establish democratic institutions. M. F. Akhundov also described the tragedy of a society indifferent to their life because of lack of education and ignorance in his narrative of "The Deceived Stars" (1857), and put forward the importance of enlightened people factor in his work. It should be noted that M. F. Akhundzadeh benefited from the historical event to avoid from harsh political sensorship.

M. F. Akhundov has taken the theme of the narrative "The Deceived Stars" from the historical work witten by Isgander Bey Munish "Tarixi-aləmarayiAbbasi" dealing with Shah Abbas I power (years of reign: 1587-1629). The work notes that the palace astrologer Jamaladdin Yazdi tells Shah Abbas that two stars Marikh and Agrab (Marikh and Scorpion) will come up to each other fifteen days after Novruz holiday and consequently this will bring Iran and its 
shah great misfortune. In order to survive the misfortune they advise the shah to renounce the power for three days. They decide to give the power to someone else desrving punishment and the misfortune of stars should befall upon him. And this person " deserving punishment" becomes Yusif Sarraj. Shah Abbas temporarily steals away for three days, and Yusif Sarraj is enthroned. After three days they search Yusif Sarraj's house and find wine. Shah Abbas' followers announce him an atheist and execute, and Shah Abbas regains the throne. So, the stars are deceived. Mirza Fatali Akhundzade took this story from the book "Tarixi-aləmarayi-Abbasi" and filtered it through his creative imagination, enriched it with new details and wrote the first Azerbaijani prose work "The Deceived Stars". He wrote about it in a letter to his friend Mirza Yusif khan: "I used this small matter in my hand as a medium expanded it through my creative imagination to disclose how rattlebrained the ministers and state heads of that time were, so that it would serve as a lesson for future generations and they wouln't believe the words and news of stupid astrologers and become an object of ridicule... ."
[Akhundov, 1988, p. 245].The comprehensive analysis of M. F. Akhundov's works shows that their analysis is actual even today. So, we considered it expedient to study the scientific ideas underlying in author's works.

\section{Devlopment}

In most of the literary works dealing with M. F. Akhundov's narrative "The Deceived Stars" wrote that the author exposed the Eastern despotism by Shah Abbas character and tried to create the character of wise, just, democratic ruler by Yusif Sarraj personality. The work has been analyzed in the example of two persons in the context of confrontation of justice and despotism. Actually, there is one more character in the work who defines M. F. Akhundzadeh's ideals. This is a chracter of people and society. Attitude of people to events interested M. F. Akhundzadeh more than the despot's method of governance, and the form of protests of certain forces- Yusif Sarraj's supporters against political governance. This was also a point arising from M. F. Akhundzadeh's education. 
The analysis of M. F. Akhundzadeh's political and scientificphilosophical views shows that the educationist philosopher understood very well that for the eradication of despotism to bring to power "a good padishah", particularly Yusif Sarraj or liquidation of despot will change nothing. The outstanding researcher Y. Garayev drawing attention to one point wrote: "In the 60s the subject of "An ideal shah" was a seen off period for M. F. Akhundzadeh. It was already the wish [want] of "good people" but not "a good shah" that worried him. [Garayev, 2002., p. 232] In his narrative "The Deceived Stars" M. F. Akhundzadeh wanted to show that everything depends upon people's position while their destiny is decided or if they agree on the governance of existing political power. The academician Isa Habibbeyli noted exactly this point writing that it was M. F. Akundzadeh who brought up the idea of people's government into Azerbaijani literature for the first time" [Habibbeyli, 2012, p. 7].

Shah Abbas is only seen in the exposition of the story. Although all hapenings are connected with Shah Abbas till the finale, the author intentionally do not move him to the forefront. The author himself speaks about the state of the country and Shah Abbas' political governance. M. F. Akhundzadeh make the Shah's viziers speak in the scene where the salvation are sought from " the star misfortune". And Shah do not interrupt any of them, and listens to them to the end though they can not show any way out. Dramatic effect reaches its highest point, and for a moment it gives its place to narration (interpretation) and self-revelation of the types creates sufficient detailed imagination of the group they belong to. Viziers are instantly ready to sacrifice the chief astrologer who delivers news from the stars but is unable to show the way out; and shah's one more quality (in fact, his lack of quality) reveals itself; and the final decision is taken not by the shah himself in dramatic situation but the chief astrologer Movlana Jamaladdin. He himself shows the way out. Shah has to give up his powers warraj'qithin fifteen days after Novruz holiday; the throne has to be given to a guilty one who has to be killed and the people don't have to see shah during this time. In this case the negative affect will have to befall on the guilty since he is the shah of Iran at 
that time" [Akhundov, 1982, 207] The guilty is not hard to find. This man is Yusif Sarraj. Mirza Fatali Akhundzadeh uses this funny story as a medium in such a serious problem. The shah's people at the head of Movlana Camaladdin do simulated power changes to impede the perseived coup d'etat by Yusif Sarraj. The author of this scenario is Movlana Jamaladdin. Yusif Sarraj's execution was just organized by Jalaladdin Mahammad Munajjim Yazdi (the prototype of Movlana Jamaladdin). He himself asserted this fact in his work " Tarixi-Abbasi". "We killed Yusif as it was his destiny, and the shah sat on the throne again [Agamali, Onullahi, 1969] And this is the essence of despotizm. M. F. Akhundzaded conveyed not only the essence of despotizm with the power of literary language but also kept it in the focus of attention in his scientificphilosophical and publicistic activities, furthermore showed the way to get rid of it. The writer wrote in his work "Kəmalüddövlə məktubları”: “ Despot is such a padishah who never obeys the laws in his work or behavior, and who always has unlimited ower and order over people's life and their property. Under the rule of such padishahs people become humble and humiliated and they are deprived of all freedom and humane rights" [Akhundov, 1987, p. 201] In another part of the work M.F. Akhundzadeh put forward the factor of people to escape from tyranny, and therefore wrote in his address to people: "You are stronger and more in number than the despot. What you need is only unanimity and identity to carry out a revolution and become free from servitude" [Akhundov, 1987, p.217] After ten years later of his "Kamaluddovla maktubları" the write continued the same vision in his article dedicated to the criticism of his friend Mirza Yusif khan's work “ Yek kəlmə The only word" and stressed the people's mission in the kingdom of tyranny once more. " ... the nation itself must acquire knowledge and be far-sighted, gain the fundamentals of unanimity and unity and then must address to the tyrant: Resign and stop living in luxury! [Akhundov, 1987, p.311] The main idea in the narrative "The Deceived Stars" is the factor of people. In the narrative it is only Yusif Sarraj and representatives of the group to which he belongs come out to the front of the despot. The author's educational ideas are clear, and he has 
expressed Yusif Sarraj's inevitable defeat in a literary way.

Who is Yusif Sarraj? There are similar and different features between as a historical personality with his identity and vision and a charachter in the narrative. We consider it necessary in brevi to stay on this point.

In all investigations associated with M. F. Akhundzadeh's literary and scientific and philosophical activities and in the novella "The Deceived Stars", it has been reluctantly touched upon the nogtavilar (people who do not recognize any creator or divine power) sect. According to studies, the leader of the nogtavilar was dervish Khosrov in the years of Shah Tahmasib's power (15241576) and, after shah's sharp warning he pretended to be far from his belief. Yusif Sarraj (Tarkeshduz) and Kichik Galandar considred dervish Khosrov their murshid (guide or leader). Dervish Khosrov has become a little active at the first years of Shah Tahmasib I, then preferred to be careful assessing the situation. He had relations with Shah Abbas I. There is information about the quiver Yusif Sarraj sewed and gave as a present to Shah Abbas. However, Shah Abbas had always control over nogtavilar. Later, Shah Abbas ordered to kill Khosrov suspecting him to revolt in Qazvin. Being arrested Kichik Galandar comitted suicide on the way to palace, while Yusif Sarraj forcefully became the leading actor of " stars story". Shah Abbas said to Yusif Sarraj: "Among the people of your family there is no one deserving the position of padishah. I declare you a padishah so that the work of this star is appropriate to your government". Shah Abbas tells him to take his seat in Shah's place and himself taking a hand stick he stands in front of him as a butler to service him. As soon as the time is over, Yusif Sarraj is murdered. According to studies, after Yusif Sarraj's death, the execution of the noqtavilar continues, and many followers of this sect are compelled to go into exile [Agamali, Onullahi, 1969]. There is no information in $M$. F. Akhundzadeh's narrative about the personal acquaintanceship between Shah Abbas and Yusif Sarraj, moreover, contrary to historical facts in the narrative Yusif Sarraj in not murdered.

We see two presentations of Yusif Sarraj in the narrative. The first presentation is given by the government representatives and the head of mollahs 
characterizes him as "sinful" and a person whose execution is necessity". The second is the author's presentation where the interesting point is the similarity of M.F. Akhunzadeh's early years of his life to those of some details in a Yusif Sarraj's autobiography. Kerbalayi Salim of Qazvin wishes his son Yusif to be a religious man. Yusif goes to Kerbalayi and Isfahan and recieves lessons fron great scholars. But he also refuses to become religious as in M. F. Akhunzadeh's youth, what's more he strongly hates them, and doesn't see himself among them [Akhundov, 1982, p. 209]. Then Yusif Sarraj's oppositionist character is depicted in the narrative. He is decidedly against Shah Abbas' power, his governance methods and he openly shows his obvious discord during talks without fear. Yusif Sarraj dismisses Shah Abbas' incapable viziers from work in his a few days' reign, sends most of them to prison and starts to tackle with those problems that always make him think. Yusif Sarraj gives orders directly connected with people's social conditions, prohibits corporal punishment, takes respective measures to discharge religious men from courts, and eventually by his order astrology is abolished. One interesting point is that Yusif Sarraj thinks about fereign economic relations in a short period of time. His meeting with representatives with Holland is also briefly described in the narrative. But, as we know, his reforms remain unfinished because of his removal from the power. As it is in history, Yusif Sarraj is dethroned, but contrary to historical events he is not murdered in the narrative. It is doubtless, M.F. Akhundzadeh by adding his literary approach to this historical event has had his goals to show Yusif Sarraj in a defeated state that led to his unfinished reforms. We think that as a whole, M. F. Akhundzadeh's has never thought about an ideal ruler. In the narrative it is not true to value Yusif Sarraj as one coming from among people and his coming to power independently without people's will and participation as M.F. Akhundzadeh's thoughts about real people's government. According to M.F. Akhundzadeh, the person at he head of the state has to make laws with the people's participation and establish a parliament. He has to carry out everything on the basis of law, and doen't have to do anything by himself, and the state has to be constitutional as in 
England. So, it is not possible to clear up the reasons of Yusif Sarraj's defeat without understanding the author's real idea in the narrative "The Deceived Stars".

The researchers provide various reasons for Yusif Sarraj's defeat. As there are tens of scientific approach, we will try to dwell on more interesting and noteworthy thoughts. The well-known literary researcher F. Gasimzadeh (mainly studied M. F.Akhundzadeh's literary activities) wrote that Yusif Sarraj came to power "purely by accident without any changes in Iran's economy" but suffered a defeat without reaching his goals and aspirations [Gasimzadeh, 1974, p.332]. As can be seen, the researcher has not explaned the reasons of defeat, though without them it is not possible to define the author's main idea in the story. The researcher $\mathrm{H}$. Mammadzadeh associated Yusif Sarraj's defeat with the historical reality: "The author do not allow Yusif Sarraj to live. To our thinking, it is not because Akhundzadeh has already approached to social events rather profoundly, he takes into account Yusif Sarraj's measures won't be able to last long, and purely for this reason he suffers a defeat. The cause of this defeat ... derives from the historical reality [Mammadzadeh, 1971, p. 165] Undoubtedly, there are enough factors arranging Yusif Sarraj's defeat. We highly appreciate the researchers' findings, at the same time we consider it necessary to provide our own considerations.

As we noted at the begining. M. F. Akhundzadeh has created the people's character, though it is not in the foreground in the narrative. In the work Shah Abbas and his supporters, as well as the character of Yusif Sarraj are seen with all parameters, but the author writes about people in some places in the work, and they are just a few sentences.

The thing is that, the great writer has neen able to introduce in a few sentences both his own idea and the reasons for Yusif Sarraj's defeat, as well as the reasons for seizing power by those who suck in people's blood. The chief architect of fabricated government changes Movlana Jamaladdin who skillfully deceives stars considers it necessary to deceive people as well. He considers necessary for people to know nothing about the devious plan [Akhundov, 1982, p. 207] This measure does not show that palace people are 
afraid of common people. By behavior of Shah Abbas' supporters the author wants to show that on the whole, people's will is nothing for this government. They can determine the destiny of people as they want without their knowledge. M. F. Akhundzade associates the existing state not only with government's endless lawlessness and tyranny but also with the level of masses who display total indifference towards his fate. In M. F. Akhundzadeh's literary description based on reality reflects that people have already accustomed to lawlessness and unjustice, and tyranny and suffering has built in them immunity, and they get surprised when they do not feel the signs of fear or horror. After Yusif Sarraj come to the throne, the attitude of townsmen to whatever they see is unexampled from standpoint of classical literary expressing of people's manner of thinking: " Everyday the people of Qazvin didn't see the flesh of men hung from the gates of fortress and didn't notice the executioners cut men into two and hang them in the gallows and put their eyes out. The situation seemed fairly strange to them" [Akhundov, 1982. p.222] M. F. Akhundzadeh laconically describes the reasons that leading Yusif Sarraj to defeat in a few sentences.

People value the shah's who relies on justice and fairness as his weakness [Akhundov, 1982, p.222]. People finally makes their decision about Yusif Sarraj: they do not need a weak padishah (in fact fair, and just)! Yusif Sarraj's old political opposition -the representatives of the old government immediately takes advantage of the opportunity. People are directly involved to dethrone Yusif Sarraj. The mutiny starts at the time that the stars promised. On the same day both the people and the stars are betrayed.

Although M. F. Akhundzadeh kept to "the star issue", he revealed the valid reasons od Yusif Sarraj's defeat who accidentally took the power. Therefore to analyze the problem only within this funny story context would preclude us to draw a sound conclusion and accurately define the author's idea.

\section{Yusif Sarraj's government} power enforcement structures and his political opposition unite. To avert bloodshed Yusif Sarraj's supporters invited the opposition side to peace, but to avoid battle was impossible, and therefore six thousand people died from 
both sides. The position of people decides the fate of the armed conflict, and the people takes the side of mutineers. Yusif Sarraj's supporters sustain a heavy defeat. So, Yusif Sarraj's defeat is determined by people's definte support for despotism alongside other objective and subjective factors. M. F. Akhundzadeh just gave people's literary description in "The Deceived Stars". Actually, it was not the idea of " a good padishah", but "good people" that made him think. In this work he tries to demonstrate the fact that for an establishment of people's government it is not enough to be a just and fair ruler at the head of the government. If people are not interested in their destiny, then to speak about the freedom of society and the building a just and democratic state is useless.

\section{The method of research}

In the research, while studying and analyzing literary and publisistic texts, the methods of historicalcomparative, analytical and typological, and idea inference and literary analysis have been used, and the principles of historicity and modernity, time and place have also been followed. In the research, we have attempted to consider the thoughts and considerations of authors with different scientific and political views in the context of that time, and assess political and idealogical tendencies referred and studied in this or other research materials.

\section{Discussion}

The analysis of studies show that M. F. Akhundzadeh as an educationist, as in Western Europe, wished for a politically mature people who are able to fight for their rights and freedom. M. F. Akhundzadeh thought that for a politically mature society to be formed, it has to be formed such a society where the freedom of thinking and expression of thoughts are possible. The studies show that in this point he was standing on the same. rank with an English philosopher John Stewart Mill from whom he benefited. J. S. Mill wrote in his essay (1859) "On liberty" : "No that it is solely, or chiefly, to form great thinkers, that freedom of thinking is required. On the contrary, it is as much and even more indispensable to enable average human beings to attain the mental stature which they are capable of. There have been, and may again be, great 
individual thinkers in a general atmosphere of mental slavery. But there never has been, nor ever, will be, in that atmosphere an intellectually active people" [Mill John Stuart, 2001, p. 33].

It is clear from the studies that M. F. Akhundzadeh developing his theoretical thoughts on the problem of people's factor and a building of a democratic society decided that if individuals is not given a freedom of expression and if they are made not to do any cultural activities, and if they do not go out of the path which their " sacred religious leaders'-the God's friends left for them, then they may become an automatic machine which without thinking, plough, cultivate and gather crop, or they look like mill-horses turning or working in the same place, they eat fodder, drink water and fall asleep, and this work may continue till the end of the world" [Akhundov, 1987, p. 355]

M. F. Akhundzadeh also showed the ways of how to break the "mill-horse" syndrome, and relinquish the mode of life once and for all continuing for thousands of years. He called people to go the way that Europen people move along and wrote: " until mid Anno-Domini (C.E. -common era) they also were compelled to show unconditional obedience to ruling sections and religious groups, but in the middle of common era there appeared thinkers and philosophers and they refused to obey, and threw off the yoke and went against Catholic faith, accomplished a revolution and declard: How come we enslaves ourselves to a few ill-bred and uneducated people though we are also human beings and have knowledge and wisdom" [Akhundov, 1987, p. 355]

As a result of analyses it becomes clear that two important problems emerge distinctly in $\mathrm{M}$. F. Akhundzadeh's thoughts. First, M. F. Akhundzadeh condemns man's enslaving, and puts forward the problem of individual's freedom, and solely rejects the tyranny of minority over majority. Second, M. F. Akhundzadeh writes that freedom is not presented to those who are being governed by those who govern, on the contrary, the members of society have to gain it only by revolution. According to analyses. we can say that in his thoughts M. F. Akhundzadeh benefited from European philosophers, including celebrated 
English poet and freedom fighter Jon Milton's (1608-1674) doctrine. Jon Milton in his speech on freedom of press in front of the parliament said (1644) that he loves the law more than anything else in life because it guarantees our personal security: “...Give me the liberty to know, to utter, and to argue freely according to conscience, above all liberties" [Milton Con, 1918, p. 57]. As a result of analyses, we can note that M. F. Akhundzadeh also as his European predecessors and contemporaries thought that freedom of thought and freedom of speech are on the top of all kinds of freedom. At the same time he understood well that at the circumstance there are profound differences between European and Azerbaijani societies , and his main task is to take people of the "ignorant world" out from the darkness to light, educate them to open their eyes, and teach them to avoid bad customs and conservative way of thinking.

\section{Conclusions}

The researches we carried out show that for the first time in the history of Azerbaijani literature M. F. Akhundzadeh in his narrative "The Deceived Stars" raised the question of importance of politically mature and active people's factor in the building of a democratic society and freedom of people to which he belonged. The writer in his work put forward the importance of people's rights and freedom, and the impossibility of gaining democratic reforms by accident. The researches carried out show that M.F. Akhundzadeh's real aim was not to create a character of a just ruler in the example of Yusif Sarraj. He wanted to show that the fate of entire people cannot be determined beyond their will. But the people who are not active politically, and who demonstrates total indifference to their fate cannot possess democratic values, and their rights are manifestly trampled. The analyses portray that, according to M.F. Akhundzadeh's thoughts, the just ruler at the head of the government still does not mean the establishment of people's government. As an educationist, he wished for politicallymature people that are able to struggle for their rights and freedom like in Western European countries. The researches enables us to infer that M.F. Akhundzadeh didn't mean the people participated in the overthrow of Yusif Sarraj's power together with unrivalled 
Periódico do Núcleo de Estudos e Pesquisas sobre Gênero e Direito

Centro de Ciências Jurídicas - Universidade Federal da Paraíba V. 8 - No 07 - Ano 2019 - Special Edition ISSN | 2179-7137 | http://periodicos.ufpb.br/ojs2/index.php/ged/index despot Shah Abbas “punishing' him to complete his mission, on the contrary he put forward the idea of educated and active people factor that he followed in the narrative"The Deceived Stars" in other works, and tried to improve and enrich the conception in which he obtained from European philosophers in this field.

\section{References}

Akhundov M. F. (1988) Works in 3 volumes /volume III. Baku: Science, 388 p.

Garayev Y. (2002). Azerbaijani literature: XIX and XX centuries. Baku: Science, $740 \mathrm{p}$.

Habibbeyli I. (2012). The light of Mirza Fatali Akhundzadeh's genius//ANAS News. Series of Humanitarian Sciences (special edition) Baku: Science, p.3-11.

Akhundov M.F. (1982). Comedies, narrative, poems. Baku: Writer, 271 p.

Hasanov A., Onullahi S. (1969, January 4th), Who is Yusif Sarraj? Literature and Art newspaper.
Akhundov M.F. (1987). Literary and philosophical works. Baku: Writer, 368 p.

Gasimzadeh F. (1974). History of XIX century Azerbaijani literature. Baku: Education, 487 p.

Mammadzadeh H. (1971) Mirza Fatali Akhundov and East, Baku: Science, 368 p.

Mill John Stuart. (2001). On Liberty 1859. Batoche Books. Kitchener, 109 p.

Milton John. (1918). Areopagitika. With a commentary by Sir Richard C. Jebb and with supplementary material. Cambridge at the University Press, $\mathrm{XL}+130 \mathrm{p}$ 